\title{
Adoption of Pedagogical Documentation in Finnish ECEC Settings
}

\author{
Charlotte Lindh ${ }^{1}\left[\right.$. Jan-Erik Mansikka ${ }^{1}$
}

Accepted: 20 January 2022 / Published online: 3 February 2022

(c) The Author(s) 2022

\begin{abstract}
According to educational research, pedagogical documentation, utilised in early childhood education and care (ECEC) settings in several countries around the world, can enhance participation and quality. However, the use of pedagogical documentation does not have an unequivocal meaning and the impact depends on the context and how pedagogical documentation is implemented and adopted. This study investigated how pedagogical documentation was used and adopted among professionals in Finnish ECEC in the wake of a new normative curriculum in 2016 that made pedagogical documentation mandatory. Theoretically, the study is based on educational research that has a close affinity to the Reggio Emilia approach to documentation. The empirical data $(\mathrm{N}=135)$ was derived from a questionnaire that was sent out to ECEC centres in one larger municipality in Finland. Our empirical data was examined using a mix of quantitative and qualitative content analysis. Our findings arrived at four different dimensions presenting various ways of implementing and adopting pedagogical documentation. We see the results as significant both in Finland and internationally, since pedagogical documentation requires interpretation by ECEC professionals and adaptation to local and regional conditions.
\end{abstract}

Keywords Early childhood education $\cdot$ Pedagogical documentation $\cdot$ Participation $\cdot$ ECEC quality

\section{Introduction}

Modern childhood has become increasingly 'documentalised', which means that various documents have become everyday elements in contemporary societies (Alasuutari et al., 2014). Documentation practices also play a central role for professionals in institutional early childhood education and care (ECEC) in many ways. It can be a matter of following children's development or learning processes. Digital platforms and social media also make it possible to share documentation with parents and stakeholders in new and often very smooth ways. Recently, pedagogical documentation has been introduced into the national core curriculum for ECEC in Finland (The Finnish National Agency for Education, 2018, pp. 39-40; hereafter NCC18). This implies that every professional within ECEC in Finland must be able to articulate how they relate to pedagogical documentation in some way or another. It has therefore been one of the most popular themes in the in-service training for ECEC

Charlotte Lindh

Charlotte.lindh@helsinki.fi

1 Department of Education, University of Helsinki, Helsinki, Finland professionals in recent years (Eskelinen \& Hjelt, 2017, pp. 35-36).

There is a considerable body of research indicating that the use of pedagogical documentation by ECEC personnel can promote children's learning, participation, and curiosity, and thus enhance ECEC quality (Alnervik, 2013; Elfström, 2013; Formosinho \& Peeters, 2019; Lenz Taguchi, 2000; Rintakorpi, 2018). However, pedagogical documentation does not have an unequivocal meaning and is understood in somewhat different ways, depending on pedagogical tradition, culture, and policy context (Dahlberg \& Elfström, 2014; Lee-Hammond \& Bjervås, 2020; Rintakorpi, 2018). In this study, we are interested in conceptions of what makes documentation 'pedagogical'. We can assume, that depending on how professionals on different levels (teachers, leaders, directors) adopt and understand the concept of pedagogical documentation, it will also affect how it is used in practice (Alasuutari \& Kelle, 2015; Hostyn et al., 2020; LeeHammond \& Bjervås, 2020; Rintakorpi, 2016). This, in turn, has consequences for how pedagogy is developed in ECEC groups, centers, and municipalities, which ultimately affect children's everyday life and opportunities for participation, learning, and development. 
In recent years, Finnish ECEC has undergone extensive and rapid changes (Fonsén \& Soukainen, 2020; Heikka et al., 2019). Since 2016, Finnish ECEC has been guided by a new national core curriculum for ECEC (revised 2018) that, to a greater extent than before, emphasises both children's perspectives and participation (Mansikka \& Lundqvist, 2019) as well as the importance of pedagogy (Fonsén \& Soukainen, 2020; Heikka et al., 2019; Rintakorpi, 2018). The new policy documents prescribe a continual development of the implemented pedagogy, which also requires participation from the children and other stakeholders (e.g. Vlasov et al., 2019). Pedagogical documentation has become a central working approach for the professionals - as a method for planning, implementing, evaluating, and developing activities (NCC, 2018, pp. 39-40; Vlasov et al., 2019, pp. 58-59, 63).

Despite its central role in ECEC policy documents, pedagogical documentation has been introduced in Finland with very little previous theoretical exploration and practical experience. When the Finnish Education Evaluation Centre (FINEC) ${ }^{1}$ evaluated the implementation of the new curriculum in 2018, pedagogical documentation was an aspect that was realised quite poorly. It was rarely utilised as a tool for systematic evaluation or to develop educational activities (Repo et al., 2019, pp. 123, 162). A recent evaluation (Juutinen et al., 2021, p. 134) points in the same direction: pedagogical documentation does not seem to have enhanced children's participation with regard to planning, implementing, and evaluating activities. Clearly, pedagogical documentation is only occasionally implemented in the extensive sense that Finnish policy documents require.

The Finnish context is, therefore, a very interesting case, and there is a need for multifarious knowledge about the implementation of pedagogical documentation within ECEC (Hostyn et al., 2020; Rintakorpi, 2018; Weckström et al., 2021). Our focus in this study was to understand how pedagogical documentation was put in practice among professionals in the Finnish ECEC field. We approach pedagogical documentation through a theoretical framework that emphasises the role of participation in qualitative ECEC. We also discuss the framework in relation to the relevant policy documents in Finland. The research question that guided our study was: how was pedagogical documentation adopted and used among professionals in Finnish ECEC?

The empirical data is based on a questionnaire $(\mathrm{N}=135)$ sent out to ECEC centres in one larger municipality in Finland. The questionnaire was divided into three parts. The

\footnotetext{
1 The Finnish Education Evaluation Centre (FINEEC) is an independent agency responsible for the evaluation of education. It operates as a separate unit within the Finnish National Agency for Education.
}

first part explored the working context and work wellbeing, while the second part was about attitudes and practices of pedagogical documentation among the professionals. The final part contained questions concerning evaluation that had less relevance to how we approach pedagogical documentation in this article. The analysis utilises the first two parts of the questionarie, and we can hopefully come back to the evaluation part in another context.

Our analysis introduces various ways of implementing pedagogical documentation. We see that knowledge about how pedagogical documentation is adopted in practice provides perspectives on both the possibilities and limitations of the development of ECEC in the Finnish context. At the same time, there is a wider significance to the study. Pedagogical documentation requires interpretation by professionals and adaptation to local conditions in other countries, and our discussion can hopefully provide a framework for such discussions.

The article has the following structure: we begin by presenting some theoretical perspectives on pedagogical documentation. After that, we discuss pedagogical documentation in relation to the Finnish context and relevant ECEC policy documents in Finland. We then move to the empirical part, discussing both methodological issues and our empirical findings. Based on an analysis of our data, we constructed four different dimensions on how pedagogical documentation is adopted. We call them reproductive documentation, indicative pedagogical documentation, developmental pedagogical documentation, and participative pedagogical documentation. We conclude with a discussion of the implications of our main findings.

\section{Approaching Pedagogical Documentation in a Participatory Framework}

The concept of pedagogical documentation has evolved from the movement of Reggio Emilia, which promoted a form of documentation, based on visualisation of the activity, and directly related to planning, developing, and evaluating everyday practice (Dahlberg \& Elfström, 2014; Dahlberg et al., 1999; Rintakorpi, 2018). Pedagogical documentation, as developed from this tradition, is closely connected to a set of values including a democratic mission built upon the image of an active and competent child, also in line with values expressed in the United Nations convention on the Rights of the Child (United Nations, 1989).

A salient feature of the Reggio Emilia approach is the emphasis that it places on children's participation and children's perspectives, also regarding learning. Adults and children are encouraged to co-negotiate in various ways about the subjects of learning, and pedagogical documentation is seen as an important tool in sustaining and developing coproduced projects that enhance learning in different ways 
(Formosinho \& Peeters, 2019; Lenz Taguchi, 2000; Weckström et al., 2021). In this tradition, pedagogical documentation can function as a tool for reflection and evaluation that enables democratic collaboration involving children, educators, guardians, politicians, researchers, and citizens (Biffi, 2019; Dahlberg \& Elfström, 2014). Clearly expressed objectives, plans, and methods for realisation form a starting point to enable the joint analysis of documented activities (Alnervik, 2018; Pichio et al., 2014). The role of pedagogical documentation has been to enhance quality for ECEC stakeholders, which can be supported by this kind of collaborative reflection (Pichio et al., 2014).

Pedagogical documentation has often been distinguished from mere documentation by the kind of reflection it can bring about (Alnervik, 2013; Elfström, 2013; Lenz Taguchi, 2010; Rintakorpi, 2018). Pedagogical documentation is sometimes connected to a practice of producing "strong" documents instead of "weak" ones, (Ferraris, 2013; Paananen \& Lipponen, 2018; Rintakorpi, 2018). Strong documents can change the social reality by pointing to the future as a basis for planning, implementation, and evaluation of activities (Rintakorpi, 2018). This means that documents can be considered strong when they evoke some kind of reflection that, in turn, leads to concrete change in the pedagogical activity. These can, for example, be changes in the physical environment, in opportunities for children's learning, or related to the interaction with children. Weak documents point more to the past (what has been achieved, learned, or done), with less power to influence the social reality. Such a distinction can be helpful but has also come under criticism. It is important not to think that "strong" documents are always worth aiming at. Changing the social reality is not a value in itself. Different kinds of documentation can encourage discussions and reflections about the current situation even without changing the social reality (see Alasuutari \& Kelle, 2015).

The choices that professionals make concerning documentation always refer to theoretical conceptions of what the child is and how children learn, which, in turn, reflect the professionals' 'prevailing values and thinking of theory and practice' (Alasuutari, 2014; Formosinho \& Formosinho, 2016; Lenz Taguchi, 2010, pp. 20-22; Sharmahd \& Peeters, 2019). These values will guide the documentation and reflection processes, whether consciously or not. When professionals base their actions and documentation on shared values and objectives, and use pedagogical documentation to communicate these to different stakeholders (children, parents, staff, etc.) this can contribute to bringing out different perspectives and voices related to day-to-day practices and offer adults opportunities to support children's learning in different, sometimes even unexpected, ways. (Alasuutari, 2014; Alnervik, 2013; Formosinho \& Formosinho, 2016; Lenz Taguchi, 2000). Pedagogical documentation used in this way can function as a multifaceted collaborative tool, enabling reflection, development, and change (Alnervik, 2013, 2018; Lenz Taguchi, 2000).

What does development and change refer to in this context? For one thing, trying to bring about change for its own sake is somewhat dubious. Instead, theoretical discourse about pedagogical documentation is, to a high degree, motivated by developing a more participative pedagogy. A participatory pedagogy requires both individual and cooperative competences among ECEC professionals (Formosinho \& de Sousa, 2019, p. 38) as well as an awareness about how power is distributed between the stakeholders involved (Alasuutari, 2014). Individual competence relates to empathic communication with children, creating time and space for them, as well as promoting their exploration and communication (Formosinho \& de Sousa, 2019, p. 38). Cooperative competences include collaboration between colleagues, teams, and institutions, as well as structures and leadership that support the processes of continuous reflection (Fonsén \& Ukkonen-Mikkola, 2019; Heikka et al., 2019; Sharmahd \& Peeters, 2019). Power is shared when various stakeholders' voices (views, opinions) affect the reflection and the activity, which can be challenging, especially if the child's view questions and challenges the professionals and the ECEC activity (Alasuutari, 2014; Lenz Taguchi, 2000). Pedagogical documentation can, in this respect, be seen as an important tool for developing a more participatory pedagogy (Formosinho $\&$ de Sousa, 2019; Formosinho \& Formosinho, 2016).

Several problematic features have been raised in relation to the practice of pedagogical documentation. Documentation may turn attention away from what is essential, namely the children themselves and their right to be participative in their own lives to learn and develop (Emilson \& Pramling Samuelsson, 2014). The lack of time for professionals to plan and discuss is also mentioned as a challenge (Alnervik, 2013; Elfström, 2013; Lenz Taguchi, 2000). Moreover, pedagogical documentation can easily be reduced to a technical procedure without intention to promote pedagogical development (Elfström, 2013; Paananen \& Lipponen, 2018; Rintakorpi, 2018), especially if the documentation practice is not integrated into a theoretical framework or wider understanding of purpose (Alasuutari, 2014; Formosinho \& Formosinho, 2016).

\section{Pedagogical Documentation and Finnish Policy Documents}

In current Finnish ECEC policy documents, such as the curriculum (NCC 18) and FINEC's guidelines (Vlasov et al., 2019), pedagogical documentation plays a central role in planning, implementing, evaluating, and developing activities. Moreover, it is seen as a continuous process where observations, documents, and interpretation create 
Table 1 Individual and institutional level of documentation in Finnish policy documents (Mansikka, 2019, p. 103)

\begin{tabular}{lll}
\hline & Content (What children say and do; institutional practice) & Pedagogical process (what we do with documentation) \\
\hline Individual level & Observing and documenting the lifeworld of children & Supporting the development of individual children \\
Institutional level & Observing and documenting institutional practice & Developing a creative and inclusive pedagogical culture \\
\hline
\end{tabular}

an understanding of pedagogical activities, with the aim of enabling children and guardians to participate in the planning, evaluation, and development of the activity (NCC 18, pp. 39-40). The section about pedagogical documentation in the curriculum seems to be in accord with the participatory framework described above.

The responsibility for the realisation and development of pedagogy in day-to-day practice is placed on ECEC teachers (NCC 18, pp. 22-31), which, according to FINEC's guidelines, requires a reflective and development-oriented approach, with pedagogical documentation as one possible method (Vlasov et al., 2019). Moreover, in Finland, every child has their own individual plan for ECEC. The purpose of the child's plan is to enable professionals, children, and guardians to reflect on how pedagogical activities are planned to support children's learning, development, and wellbeing (NCC 18, pp. 10-12; Act 540/2018, §23). Pedagogical documentation is seen as an important tool in the construction of children's plans. Furthermore, systematic documentation ought to play an important role when group activities are planned and implemented, or when educational environments and operational culture are developed (NCC 18, pp. 39-40). In fact, documentation collected over a long period of time is an important part of evaluating day-to-day activities as well as the staff's self-evaluation of activities (NCC 18, p. 40).

We can see that pedagogical documentation in the Finnish policy documents refer to activities to be performed with a focus on both individual and institutional levels. The individual level refers to the observations and reflections on experiences of individual children. The institutional level is the case when not only children, but the operational culture as a whole, become the focus of interest. Both levels are presented in Table 1.

In line with our previous discussion, documentation can also be seen either in a dimension of content to be documented or as a process of development. The turn from "content" to "process" can be seen as the transition from mere documentation to pedagogical documentation because it is the process of reflection on the content that is essential for pedagogical documentation, with the potential to affect the current views and action of the professionals.

Pedagogical documentation has been given an important role in the recent reforms and has become an essential part of the rhetoric among ECEC professionals in Finland. It is, however, unclear for many what it means in practice. The descriptions in the curriculum (NCC18) are rather vague, pointing at its processual character but with an emphasis on the individual level and children's plans. According to Lee-Hammond and Bjervås (2020), policy documents have a profound influence on how professionals view pedagogical documentation and what they consider it to be. There are currently no studies about how professionals in Finland understand the concept, but it would be plausible to believe that they understand it as being closely related to policy documents.

\section{Methodology}

\section{Data Collection}

Data was collected through an electronic questionnaire (E-lomake) in November 2020. The survey was distributed by email to 119 ECEC directors and co-directors representing 107 childcare centres in one larger municipality in Finland, targeting staff of various professions working with child groups. The directors were asked to pass the questionnaire to their ECEC personnel who worked with the children. It is often challenging to get ECEC professionals to participate in questionnaires and we were hoping the directors would view the study as being significant and encourage their staff to answer. The directors were also called to ensure that they had received the survey. Adequate information was initially presented in the mail and in the beginning of the questionnaire to assure voluntariness and the competence of respondents to decide whether to participate or not (European textbook on ethics in research, 2010). By choosing a larger municipality, we obtained a wider field of different actors (both municipal and private) that operate in the Finnish ECEC. At the same time, we bore in mind that a large municipality might differ in its operational ECEC culture from smaller cities or rural areas. Our choice of method and data collection reflects our aspiration to understand how pedagogical documentation is put in practice on a somewhat general level. It is, however, likely that our informants may have been somewhat more interested in the topic than average.

Due to a low response rate (approximately 5\%) for the electronic version, a paper version of the questionnaire was also sent by post to childcare centres in December 2020, and the directors were informed by email. We cannot know 
for sure, but can assume, that the low response rate has to do with the fact that not all professionals within ECEC in Finland have regular access to a computer. Also, a heavy workload presumably effected the response rate. Four directors replied that they did not want to pass on the questionnaire due to heavy workloads, because other questionnaires were also addressed to their personnel during the same time. There were occasional cases of personnel with foreign languages (English, Russian or French) who were unable to answer the questionnaire. The paper version brought in more answers than the online version. The combination resulted in a total of 135 professionals responding to our questionnaire, partly an online version $(\mathrm{N}=55)$ and partly a paper version $(\mathrm{N}=80)$. We do not know how many professionals working in the childcare centres in the municipality received the questionnaire, but we estimate the response rate to be about $10-15 \%$, provided that the questionnaire reached $1200-1500$ ECEC professionals. Our data does not reveal from which childcare centres our respondents came from, but by striving to reach every childcare centre in the municipality (municipal and private centres) we can assume that our respondents represent a range of different socio-economic environments.

Prior to data collection we received consent from municipality authorities to collect data in the municipality as well as from one of the private actors, who required separate consent. All data collection followed ethical guidelines, protecting the anonymity of participants both at the individual and childcare unit level. Respondents interested in participating in further research could leave their contact information in the questionnaire without any further obligation. The data has been saved and managed securely FSD (2021). In line with the recommendations in Finland, no independent ethical review was needed, as neither the research nor research results were likely to cause harm to the participants (TENK, 2019).

\section{Questionnaire}

The questionnaire contained three themes and was designed for this particular study. The questions were related to the overall research objective, reflecting both our experience of the field as well as theoretical perspectives on pedagogical documentation. Theme three had less relevance for how we approach pedagogical documentation in this article and was therefore not included. Because the municipality was in a bilingual area of Finland, the questionnaire was created in both Finnish and Swedish. Those who filled in the questionnaire online were required to answer all questions, whereas responses in the paper version could contain some missing values. However, the difference between these two forms of collection was not considered to be significant in relation to our analysis.
Table 2 The age of respondents

\begin{tabular}{lll}
\hline Age & Frequency & Percent \\
\hline 20-30 years & $\mathrm{N}=26$ & 19 \\
31-40 years & $\mathrm{N}=36$ & 27 \\
41-50 years & $\mathrm{N}=30$ & 22 \\
51-60 years & $\mathrm{N}=26$ & 19 \\
Over 60 years & $\mathrm{N}=9$ & 7 \\
\hline
\end{tabular}

Table 3 Respondents' working years

\begin{tabular}{lll}
\hline Working years & Frequency & Percent \\
\hline $0-10$ & $\mathrm{~N}=70$ & 52 \\
$11-20$ & $\mathrm{~N}=31$ & 23 \\
$21-30$ & $\mathrm{~N}=19$ & 14 \\
$31-40$ & $\mathrm{~N}=12$ & 9 \\
\hline
\end{tabular}

The questionnaire was initially piloted by six ECEC teachers, resulting in small modifications. The final questionnaire comprised 40 overarching questions altogether (with three themes). The total number of questions used in this study was 31, of which 6 were basic demographic questions; theme one (Working context and work wellbeing) contained 13 questions and theme two (Pedagogical documentation) contained 12 questions. Theme one consisted of Likert scale item (1-5) questions, Likert scale multi-item statements, and open-ended questions. One example from this theme was: I can carry out my work during working hours $(1=$ do not have enough time, $5=$ have plenty of time). Theme two consisted of many different types of questions: Likert scale item (1-5) questions, Likert scale (1-5) multiitem statements, a question that required ranking in order to obtain a better view of respondents' opinions, open-ended questions, closed-ended questions with opportunity to comment, and multiple-choice questions with the opportunity to add the respondents' own choices. An example of an open-ended question from theme two was: What have you documented during the last week? Why did you choose to document what you documented?

\section{Sample}

135 ECEC professionals participated in the study, of whom 96\% ( $\mathrm{N}=130)$ were females. The age distribution of the respondents is presented in Table 2 and their working years in Table 3.

In Finland, ECEC professionals work in multiprofessional teams consisting of teachers, child carers, and social pedagogues with at least one pedagogically educated university-qualified ECEC teacher (Bachelor of Early Childhood Education). The roles and responsibilities of different 
Table 4 The respondents' professions

\begin{tabular}{lll}
\hline Profession & Frequency & Percent \\
\hline Early childhood education teachers & $\mathrm{N}=89$ & 66 \\
Childcarers & $\mathrm{N}=35$ & 26 \\
Special education teachers & $\mathrm{N}=6$ & 4 \\
Social pedagogues & $\mathrm{N}=4$ & 3 \\
Other & $\mathrm{N}=1$ & 0.7 \\
\hline
\end{tabular}

Table 5 The age of the child groups respondents worked in

\begin{tabular}{lll}
\hline Child groups & Frequency & Percent \\
\hline Children aged 0-3 & $\mathrm{N}=30$ & 22,2 \\
Children aged 3-5 & $\mathrm{N}=49$ & 36,3 \\
Children aged 3-6 & $\mathrm{N}=16$ & 11,9 \\
Children aged 5-7 & $\mathrm{N}=4$ & 3 \\
Children aged 6 & $\mathrm{N}=15$ & 11,1 \\
Children aged 0-7 & $\mathrm{N}=21$ & 15,5 \\
\hline
\end{tabular}

professions are clarified by legislation (Act 540/2018). Table 4 presents what professions the respondents worked in.

The age group compositions in which respondents worked in were diverse but the most common age groups were children 0-3 and 3-5 years, presented in Table 5.

\section{Data Analysis}

In this study, our empirical data was analysed through a systematic classification process of coding and identifying themes and patterns using descriptive statistics and content analysis. Both closed-ended questions and Likert scale items (including multi-item questions) were analysed by frequency. Additionally, relevant open-ended questions describing either the context or how pedagogical documentation was used were inductively categorised and reported by frequency. SPSS was used as the software programme. Content analysis was used when the aim was to provide contextual knowledge and understanding of a phenomenon (Hsieh \& Shannon, 2005) in this study, describing the context and how pedagogical documentation was used.

We have also used content analysis to expand the actual data (Hsieh \& Shannon, 2005), which, in our case, means expanding our analysis to explore various ways in which pedagogical documentation was adopted by ECEC professionals in the Finnish context. This was done through qualitative analysis, mostly leaning on open-ended questions. By immersive reading of data to identify key content (see Mayring, 2000), four questions were selected as a starting point for a qualitative analysis. The analysis was performed in steps. First, the four questions were compiled, whereby three tentative categories of pedagogical documentation emerged inductively. Then, the categories were elaborated in greater detail and nuance. The similarities and differences between the categories and tentative codes were visualized (Drisko \& Maschi, 2015), after which criteria for coding rules were deductively obtained to form a coding agenda. The coding was, therefore, both inductively and deductively derived (Mayring, 2000). Finally, a formative reliability check of the emerging categories and coding frame, performed by both researchers separately, led to modifications of the categories, which were expanded to a total of four. Thus, the analysis was carried out in loops and cross-checked (Drisko \& Maschi, 2015; Mayring, 2000), and was also discussed during a doctoral seminar.

Consequently, this study combines qualitative and quantitative techniques into a single study method, being more of a hybrid or blended research methodology than a true form of mixed methods research (Drisko \& Maschi, 2015; Hsieh $\&$ Shannon, 2005). In such studies the results are limited to the sample and are only representative for the research participants (Drisko \& Maschi, 2005).

\section{Results}

This section consists of our results, divided into three parts that together shed light on how pedagogical documentation is used and adopted. These are: 1) Working context and work wellbeing; 2) Motives and procedures for documentation; and 3) How professionals adopt pedagogical documentation. As we have seen, pedagogical documentation is always conducted in a particular context. Therefore, we begin by presenting results about how the respondents experience their own operational culture and wellbeing within ECEC. After that we look at descriptive data concerning respondents' documentation. Finally, we analyse how our respondents reported the way they put pedagogical documentation into action.

\section{Working Context and Workwellbeing}

Our results concerning the context of ECEC rely on items from our questionnaire with significance to the respondents' working context and work wellbeing. We have brought together nine items that relate to the theme, and we can see that almost every item reaches up to grade 4 on the Likert scale (see Table 6). The only aspect that stood out was about lack of time and difficulties in carrying out the work during working hours. This particular item also had the widest deviation, most likely due to different job descriptions between professions (teacher, childcarer, social pedagogue, special education teacher). When it comes to experiencing respect and participation as a professional, the overall ratings 
Table 6 Working context and wellbeing, $(\mathrm{N}=135)$

\begin{tabular}{lll}
\hline & Mean & SD \\
\hline 1. Knowledge of national core curricula & 4.03 & 0.743 \\
2. Opportunities to get acquainted with local curricula & 4.23 & 0.900 \\
3. Local curricula support my work & 3.96 & 0.844 \\
4. Work carried out during working hours & 3.18 & 1.105 \\
5. Everyone is respected and listened to in my team & 4.43 & 0.815 \\
6. Further training when needed & 4.15 & 0.945 \\
7. Further training supports and inspires my work & 4.18 & 0.884 \\
8. Support from superior & 4.07 & 0.943 \\
9. Feeling of overall work wellbeing & 4.32 & 0.760 \\
\hline
\end{tabular}

Respondents' view of nine aspects affecting their working context ( $1=\mathrm{I}$ do not agree, $5=$ strongly agree)

Fig. 1 Most significant separate motive for documentation, $(\mathrm{N}=126)$ approach as well as to pedagogical know-how. The need for support, on the other hand, gravitated around three areas: pedagogical leadership, time, and resources, which to a great extent were related to tools and guidance for children in need of support.

\section{Motives and Procedures for Documentation}

The practice of pedagogical documentation seems to depend on many different aspects. In this context, we present results that have to do with why, what and how professionals in Finnish ECEC document.

We provided the respondents with a list of nine different motives for documenting in the questionnaire that resulted in a generalised view on why pedagogical documentation

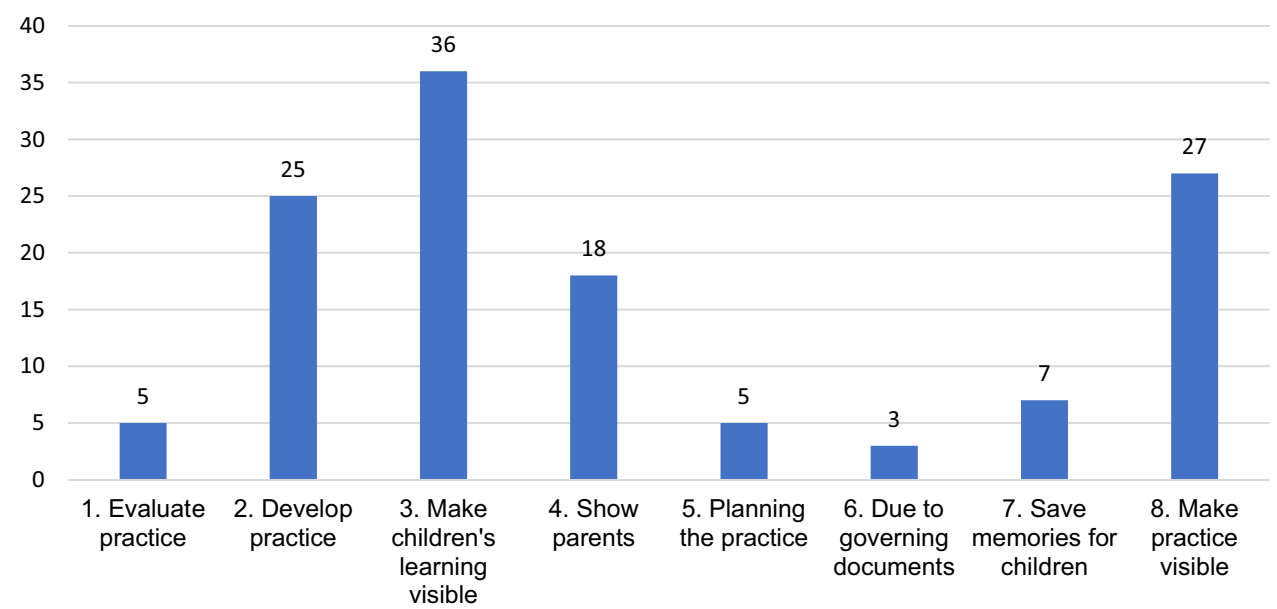

were surprisingly high, which can be interpreted as supportive preconditions for dialogue and collaborative reflection among personnel.

We can see from Table 6 that there are many structural items that support the working context that presumably affect the overall experience of wellbeing at work in a positive way. The table also indicates a strong professional identity among our respondents, as they are mainly well acquainted with policy documents both in theory and practice. Moreover, they felt that further training supports their work and that they experience mostly respectful collaboration within their teams.

The respondents also displayed confidence in their own abilities when, in relation to another question, they came up with significantly more aspects that they "master well" ( $79 \%$ of the respondents mentioned at least one) than aspects "needing support" (48\% of the respondents mentioned at least one). The things that were well mastered were mostly related to a sensitive and child-centred is utilised in day-to-day activities. Various forms of visualisation obtained the highest scores. In addition, we also wanted to distinguish which of the motives was perceived as the most significant for documenting, as presented in Fig. 1.

The results presented in Fig. 1 further strengthen the conception that various forms of visualisation are the most frequently occurring motivators. In total, $65 \%(3 .[\mathrm{N}=36]$ 8. [N=27]; 4. [N=18]; 7. [N=7]) of our respondents chose them as the most significant alternatives. However, this data does not say much about how these visualisations are utilised in practice. We can say that some of the motivators indicated a tendency towards reflection and possible change. The category of developing practice $(18 \%, \mathrm{~N}=25)$ stands out here because documentation is explicitly connected to professional development, pointing at a process which is usually seen at the core of pedagogical documentation. The items of planning $(3,7 \%, \mathrm{~N}=5)$ and evaluating practice $(3,7 \%, \mathrm{~N}=5)$ also indicate concrete change and development. This means 
Fig. 2 Aspects documented last week, $(\mathrm{N}=115)$
Aspects documented last week

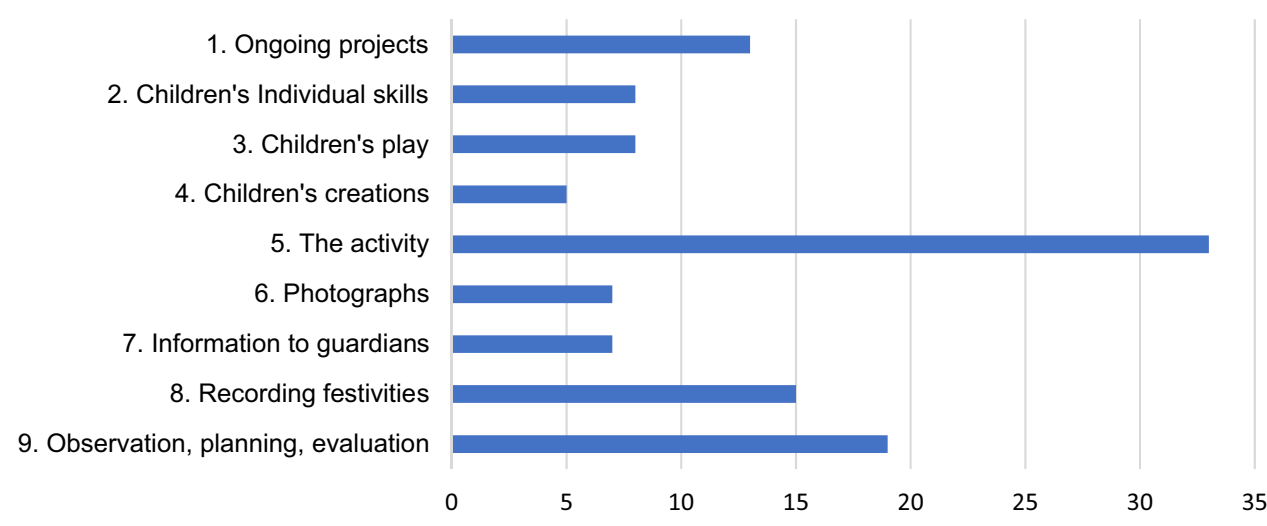

that $25 \%$ of respondents reported pedagogical documentation used in a way that enhances reflection and development as most significant. However, this result still does not reveal how reflection and development in this pedagogical context is understood or implemented by respondents. Employers' requirement was an option but was not seen as the most significant item by any of our respondents.

A fundamental prerequisite for pedagogical documentation is obviously that some kind of documentation is performed. Of the whole sample, $85 \%(\mathrm{~N}=115)$ of the respondents reported having documented last week, whereas $15 \%(\mathrm{~N}=20)$ reported not having documented at all. The affirmative answers were inductively interpreted and categorised into nine different categories, illustrating what aspects respondents were documenting, reported by frequency in Fig. 2.

When respondents were asked what and why they documented, "what" was answered more frequently and in a more detailed way than "why". In spite of the fact that documentation is performed, the objectives for documentation are somewhat vague. The effect of the pandemic is visible in the category "Recording festivities" (Fig. 2), which relates to sharing recordings of Christmas festivities with parents when they have not been able to participate in person.

The most common method utilised for documentation were photos $(96 \%)$, notes $(82 \%)$, video $(51 \%)$, and audio (11\%). Other documentation methods were children's drawings and other work, interviews, storytelling, forms and surveys, portfolios, and documentation walls as well as various applications on social and digital media (blogs, Facebook, Instagram, Youtube, Pedanet, etc.). These results correlate well with earlier studies (e.g. Knauf, 2015; Rintakorpi, 2016, 2018) and show respondents utilising a wide range of different methods of documentation. It is highly probable that the use of various media as a form of communication has become increasingly important during the pandemic, when parents are prohibited from entering ECEC centres.
When asked about how well respondents think they know how to use pedagogical documentation in their work, $65 \%$ of our respondents graded their knowledge as excellent or very good, whereas $27 \%$ graded their knowledge as good. Only $32 \%$ report having attended development projects or further training concerning pedagogical documentation, whereas $68 \%$ have not. These results converge with the respondents' high confidence in their own pedagogical knowhow and familiarity with curricula. However, this does not reveal how our respondents understand or implement the concept of pedagogical documentation. We will delve into this in the following section.

\section{How Professionals Adopt Pedagogical Documentation}

Our analysis of how professionals adopt pedagogical documentation is built upon a closer familiarity with some parts of our data. We focus on four questions that we considered to describe reliably how the respondents approach pedagogical documentation. These questions laid the foundation for our interpretation and were about (a) what they had documented the previous week and why (they did it); (b) advantages in using documentation; (c) disadvantages in using documentation; as well as (d) what they thought of as important when it comes to documenting in their team. Both questions (a) and (d) have been dealt with briefly earlier (Table 6 and Fig. 1). Compiling these four questions enabled us to produce a more holistic interpretation of the professionals' stance. Leaning on the theoretical background and policy documents, we tried to capture different variations and dimensions in the data that would give us a richer picture of the phenomenon in question.

Our starting point for preparing the codes for analysis was based on the concepts that the professionals used in relation to pedagogical documentation and looking at how well the data corresponded to the theoretical concept of pedagogical documentation. Three conceptions guided us here. Firstly, 
and obviously, some kind of documentation has to be realised, i.e., something is documented. Secondly, there is a purpose and an objective for the documentation that is reflected on, either in a retrospective or a prospective way. This also includes some form of assessment or evaluation. Thirdly, the prospective aim of documentation can be viewed in a narrower or a broader dimension (Lenz Taguchi, 2013). A narrower aim entails a more transmissive pedagogy containing limited reflection and assessment, whereas a broader aim is more participative and development-oriented (Formosinho $\&$ Formosinho, 2016). Additionally, we were interested in whether children's or other stakeholders' participation was mentioned.

The different answers (containing all four questions) of individual respondents were divided into categories based on an interpretation and overall assessment of how well they corresponded to the codes for a category. To further clarify the categorisation, frequently used concepts guided the division. Our analysis resulted in four categories. The first category is documentation that does not have a clear aim or purpose, or, if it has, it is retrospective and not oriented towards the future. We call this reproductive documentation because it does not have the characteristics of a pedagogical process. It is documentation that produces documents that do not include reflection and do not really have an impact on social reality. It might be a document with the purpose of collecting memories or showing things to parents or stakeholders.

The second category has, opposed to the first one, a prospective aim, which also makes it pedagogical. We call it indicative pedagogical documentation. It indicates a development process as it includes reflection related to objectives. The objectives are still quite vague and remain narrow and focused on assessing what has already been done and why. The "why" could be used to plan, develop, or change the activity, but these features do not appear in this category.

The third category is more explicit regarding development and is called developmental pedagogical documentation. In this category documentation is mostly focused on specific skills or learning areas, and reflection forms the basis for planning future activities or learning. As the documentation is considered when planning future activities, it can clearly affect the development of pedagogy when plans are put into action. The development refers to clear objectives, but the objectives are still narrow as they focus on specific skills or aspects. Moreover, children are not mentioned as participants in the process.

The last category has the broadest view, and brings reflection, participation, and development into the aim of documentation, together with a participatory practice. We call it participative pedagogical documentation. In this category the objectives are clear and broad as they also include the operational culture. Children are involved in the evaluation process and professionals are viewed as learners in the process. As the professionals see themselves as learners, this shows a high tendency to implement change and development.

The following table (Table 7) illustrates the four different dimensions of how pedagogical documentation is adopted from our material. The table also shows how the respondents are divided regarding the dimensions. The codes consist of objectives, reflection, evaluation, and documentation outcomes that relate to frequently occurring concepts. The examples represent a typical answer for a particular dimension.

Our respondents operated with a concept, pedagogical documentation, which is understood in numerous ways. The most obvious distinction is between the first and the second categories, which draws a line between "documentation" and "pedagogical documentation". The distinction is motivated from both theoretical literature and policy documents, where pedagogical documentation is defined as a form of documentation used for pedagogical purposes to promote, support, and develop an activity (Dahlberg \& Elfström, 2014; Mansikka, 2019; NCC 18; Paananen \& Lipponen, 2018; Rintakorpi, 2018). Therefore, documentation that lacks future-orientation is not pedagogical. In contrast, future-oriented pedagogical documentation functions as a tool for potential change and development: it is an "active agent" (Lenz Taguchi, 2010).

It is important to read the four dimensions as fluid, in which transitions from one dimension to another are not very distinct. It is also appropriate to conceive of the transitions as an expansion, rather than movement from one level to another. The four dimensions illustrate a movement from mere documentation to a participative pedagogical documentation via some intermediate levels, as visualised in Fig. 3.

The four dimensions form a whole that describes how pedagogical documentation can be perceived and realised. The different dimensions may well exist at the same time and influence each other in daily activities. This means that pedagogical documentation in a child group or ECEC setting is not necessarily realised along only one dimension at a time. Despite fluctuations between dimensions, the direction of the development of pedagogical documentation needs to be emphasised when the aim is increased participation. From this perspective, pedagogical documentation can function as a tool that supports development from a transmissive pedagogy towards a more participative pedagogy (Formosinho \& Formosinho, 2016). 


\section{Discussion and Conclusion}

Qualitative ECEC activity in Finland today is often characterised by a participative, sensitive, and reflexive development-oriented operational culture in which pedagogical documentation can function as a tool for improving participation and development. Our study gives an indication of how the "working approach" of pedagogical documentation has been received among the professionals who responded to this study. Our methodological framework does not allow us to create a deep-seated analysis, but can still provide a picture of how pedagogical documentation has emerged in the Finnish ECEC context. As we have seen in this study, there is a wide field of conceptions and practices in relation to pedagogical documentation, probably reflecting ambiguities in the policy documents.

From our perspective, the Finnish ECEC curriculum has some problematic formulations concerning pedagogical documentation. The concept of pedagogical documentation is described as a method to guide the planning, development, and evaluation of pedagogy. When pedagogical documentation is utilised as "just a method" that does not include values, it most likely becomes only a documentation and visualisation of activities, but is not directed at enhancing participation. The curriculum also describes pedagogical documentation mainly in relation to the individual child but not in conjunction with the operational culture, potentially narrowing the scope of pedagogical documentation. The holistic perspective on pedagogical documentation in this study, which affects the entire activity, implies that pedagogical documentation and enhancement-led evaluation, as described in the Finnish policy documents, become closely related concepts (see Vlasov et al., 2019).

Our results reflect previous research concerning pedagogical documentation in Finnish ECEC, where visualisation stands out. We can see, however, that a considerable number of our respondents do not use documentation in a future-oriented way. Instead, it is primarily a tool for illustrating activities and for collecting memories, a way to adopt the concept we call reproductive. In such a perspective, all kinds of documentation are seen as pedagogical. Our study shows that it is meaningful to make a distinction between mere documentation and pedagogical documentation, but also in different forms of future-oriented reflection, depending on how strongly the documents are integrated into the participative culture. Overall, only a few respondents display the practice of pedagogical documentation as an enabling process that leads to wider development and change, corresponding to the Finnish ECEC policy documents. Still, the majority of the respondents had strong confidence in their own professional ability and knowledge of pedagogical 
Fig. 3 The expanding circles of pedagogical documentation

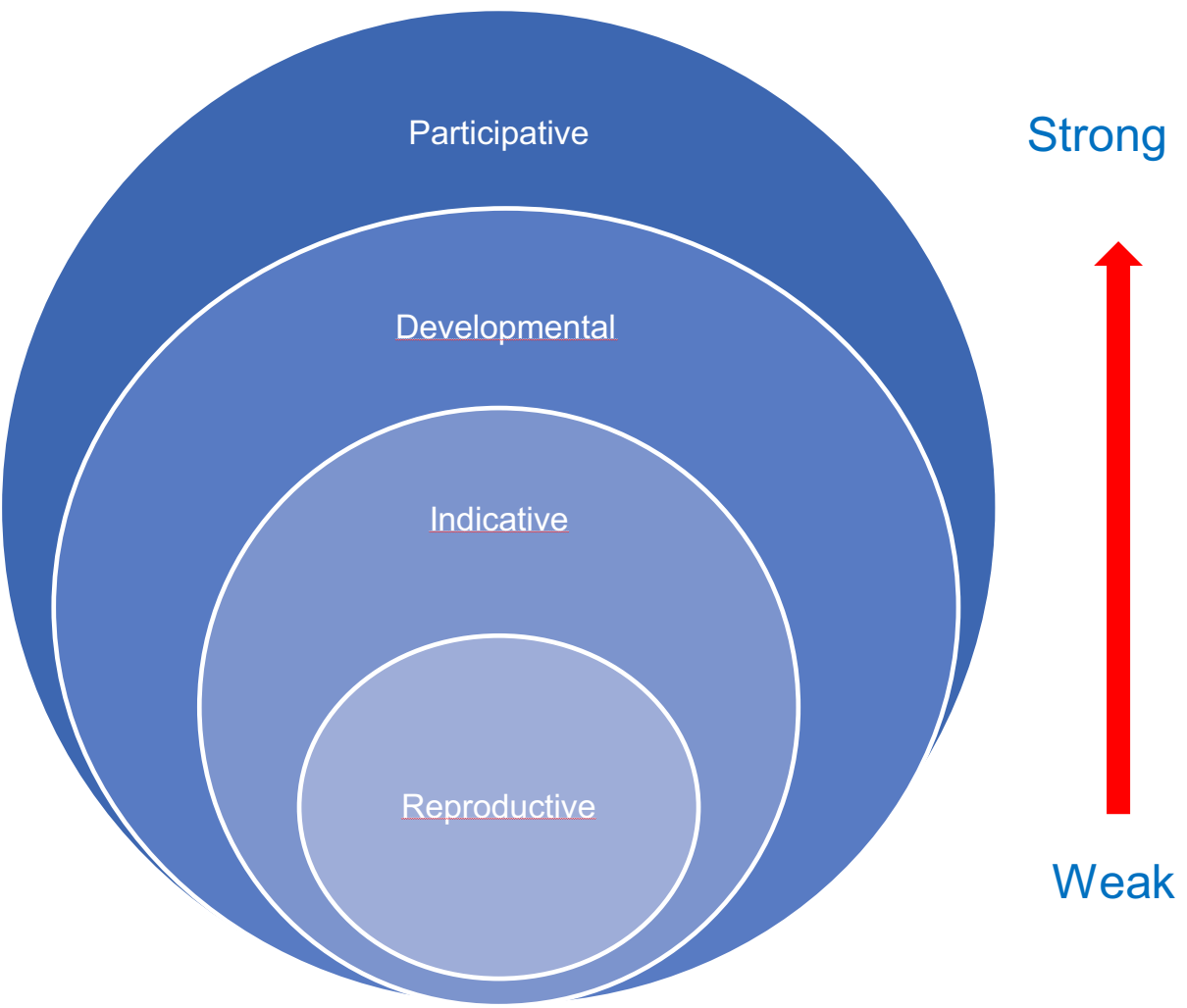

documentation. This raises the question of whether a need for development can be recognized.

Although our results show that conceptions of pedagogical documentation are diverse, the underlying conditions are interpreted as being favourable for the development of participatory pedagogical documentation in this Finnish ECEC context. Documentation is performed to a considerable degree and there are positive indicators on work wellbeing, including good opportunities for in-service training and professional development. The curriculum is also perceived to support the daily work. These aspects form a solid basis for developing a conscious use of pedagogical documentation. Additionally, leaders and directors were perceived to be supportive at work, which is significant for the development of the pedagogical and educational culture. Our study does not, however, shed light on the leaders' or directors' knowledge or way of adopting pedagogical documentation, and we cannot therefore say anything about their role in developing this specific aspect.

The question of why some of our respondents utilise pedagogical documentation in a more participative way than others still remain unanswered. A similar study by Knauf (2015) in a German context found that the ECEC centres that documented in a participative way were working explicitly with a Reggio Emilia approach. This is not highly likely in the Finnish context. However, further empirical research is needed that investigates on a much more concrete level how pedagogical documentation is negotiated and put into practice. This study can function as a framework for such studies.

The main purpose in this study was to understand how a relatively new concept has been integrated into practice. But we have also sought to increase awareness of pedagogical documentation as a multifaceted tool by presenting various aspects that influence how it can be used and adopted. Traditionally, photographs have been taken to commemorate a common event. This can be valuable although it does not necessarily actively promote a more participative pedagogy. We argue that by exploring and developing the use of pedagogical documentation in practice, it is likely that we also support the development towards a more participative early childhood education. Our theoretical model, with its four different categories, can elucidate different forms of understanding from the ECEC field regarding what pedagogical documentation is about. By pointing at the inherent possibilities of pedagogical documentation in our study, we wish to support the further development of pedagogical documentation, both on a theoretical and a practical level, not only in the Finnish context but also in other countries.

Acknowledgements This study was supported by Svenska Kulturfonden (Grant No. 167462).

Author Contributions Both authors made substantial contributions to the design, analysis and interpretation of data as well as critically revising and approving the version to be published. 
Funding Open Access funding provided by University of Helsinki including Helsinki University Central Hospital.

Data Availability All data and material as well as software applications support the claims in the study and comply with field standards.

Code Availability Microsoft word, SPSS.

\section{Declarations}

Conflict of interest The authors have no relevant financial or nonfinancial interests to disclose. Both authors certify that they have no affiliations with or involvement in any organization or entity with any financial interest or non-financial interest in the subject matter or materials discussed in this manuscript. The authors have no financial or proprietary interests in any material discussed in this article.

Ethical Approval This study is based on a survey, the research or research results do not cause potential harm for participants why no ethical review was needed (TENK, 2019).

Consent to Participate Prior to data collection consent from municipality authorities to collect data in the municipality as well as from one of the private actors who required separate consent was received. The research participants have received information prior to attending the study to assure voluntariness and the competence of respondents to decide whether to participate or not.

Consent for Publication No information that identifies participants' or participants' workplace was gathered for the study.

Open Access This article is licensed under a Creative Commons Attribution 4.0 International License, which permits use, sharing, adaptation, distribution and reproduction in any medium or format, as long as you give appropriate credit to the original author(s) and the source, provide a link to the Creative Commons licence, and indicate if changes were made. The images or other third party material in this article are included in the article's Creative Commons licence, unless indicated otherwise in a credit line to the material. If material is not included in the article's Creative Commons licence and your intended use is not permitted by statutory regulation or exceeds the permitted use, you will need to obtain permission directly from the copyright holder. To view a copy of this licence, visit http://creativecommons.org/licenses/by/4.0/.

\section{References}

Act on Early Childhood Education and Care. (540/2018). Ministry of Education and Culture.

Alasuutari, M. (2014). Voicing the child? A case study in Finnish early childhood education. Childhood, 21(2), 242-259. https://doi.org/ $10.1177 / 0907568213490205$

Alasuutari, M., \& Kelle, H. (2015). Editorial. Children \& Society., $29,169-173$.

Alasuutari, M., Markström, A.-M., \& Vallberg-Roth, A.-C. (2014). Assessment and documentation in early childhood education. New York: Routledge. https://doi.org/10.4324/9781315818504

Alnervik, K. (2013). Men så kan man ju också tänka! School of Education and Communication, Jönköping University.

Alnervik, K. (2018). Systematic documentation: Structures and tools in a practice of communicative documentation. Contemporary
Issues in Early Childhood, 19(1), 72-84. https://doi.org/10.1177/ 1463949118762147

Biffi, E. (2019). Pedagogical documentation as a shared experience of understanding childhood. In J. Formosinho \& J. Peeters (Eds.), Understanding pedagogical documentation in early childhood education revealing and reflecting on high quality learning and teaching (pp. 67-80). Routledge.

Dahlberg, G., \& Elfström, I. (2014). Pedagogisk dokumentation i tillblivelse. Pedagogisk Forskning i Sverige., 19(4-5), 268-296.

Dahlberg, G., Moss, P., \& Pence, A. (1999). Beyond quality in early childhood education and care: Postmodern perspectives. Falmer Press.

Drisko, J., \& Maschi, T. (2015). Content analysis. Oxford Scholarship Online, November 2015.

Elfström, I. (2013). Uppföljning och utvärdering för förändring pedagogisk dokumentation som grund för kontinuerlig verksamhetsutveckling och systematiskt kvalitetsarbete i förskolan. Disseration. Stockholms universitet, barn och ungdomsvetenskapliga institutionen.

Emilson, A., \& Pramling Samuelsson, I. (2014). Documentation and communication in Swedish preschools. Early Years, 34(2), 175187. https://doi.org/10.1080/09575146.2014.880664

Eskelinen, M., \& Hjelt, H. (2017). Varhaiskasvatuksen henkilöstö ja varhaisen tuen toteuttaminen. Valtakunnallinen selvitys 2017. Opetus- ja kulttuuriministeriön julkaisuja 2017:39.

European textbook on ethics in research (free PDF version). (2010). Retrieved March 23, 2021, from http://ec.europa.eu/research/ science-society/document_library/pdf_06/textbook-on-ethicsreport_en.pdf

Ferraris, M. (2013). Documentality: Why it is necessary to leave traces. Fordham University Press.

Finnish National Core Curriculum for Early Childhood Education and Care. (2018). Regulations and guidelines: 3c.

Finnish Social Science Data Archive. (FSD). Retrieved March 16, 2021, from https://www.fsd.tuni.fi/en/services/data-manag ement-guidelines/data-management-planning/

Fonsén, E., \& Soukainen, U. (2020). Sustainable pedagogical leadership in Finnish Early Childhood Education (ECE): An evaluation by ECE professionals. Early Childhood Education Journal, 48(2), 213-222. https://doi.org/10.1007/s10643-019-00984-y

Fonsén, E., \& Ukkonen-Mikkola, T. (2019). Early childhood education teachers' professional development towards pedagogical leadership. Educational Research, 61(2), 181-196. https://doi. org/10.1080/00131881.2019.1600377

Formosinho, J., \& de Sousa, J. (2019). Developing pedagogic documentation. In J. Formosinho \& J. Peeters (Eds.), Understanding pedagogical documentation in early childhood education, revealing and reflecting on high quality learning and teaching (pp. 32-51). Routledge.

Formosinho, J., \& Formosinho, J. (2016). Pedagogy-in-participation, the serach for a holistic praxis. In J. Formosinho \& C. Pascal (Eds.), Assessment and evaluation for transformation in early childhood (pp. 26-55). Routledge.

Formosinho, J., \& Peeters, J. (2019). Understanding pedagogic documentation in early childhood education, revealing and reflecting on high quality learning and teaching. Routledge.

Heikka, J., Pitkäniemi, H., Kettukangas, T., \& Hyttinen, T. (2019). Distributed pedagogical leadership and teacher leadership in early childhood education contexts. International Journal of Leadership in Education., 24(3), 333-348. https://doi.org/10. 1080/13603124.2019.1623923

Hostyn, I., Mäkitalo, A.-R., Hakari, S., \& Vandenbussche, L. (2020). The professional actuation of pedagogical documentation in Belgian and Finnish early childhood settings. Early Childhood Development and Care, 190(3), 400-413. https://doi.org/10. 1080/03004430.2018.1475368 
Hsieh, H. F., \& Shannon, S. E. (2005). Three approaches to qualitative content analysis. Qualitative Health Research, 15(9), 1277-1288. https://doi.org/10.1177/1049732305276687

Juutinen, J., Siippainern, A., Marjanen, J., Sarkkinen, T., Lundkvist, M., Mykkänen, A., Raitala, M., Rissanen, M.-J., \& Ruokonen, I. (2021) Pedagogisia jatkumoita ja ilmaisun iloa! Viisivuotiaiden pedagogiikka ja taito- ja taidekasvatuksen nykytila varhaiskasvatuksessa. Kansallinen arviointikeskus. Julkaisut 9:2021.

Knauf, H. (2015). Styles of documentation in German early childhood education. Early Years, 35(3), 232-248. https://doi.org/ 10.1080/09575146.2015.1011066

Lee-Hammond, L., \& Bjervås, L.-L. (2020). Pedagogical documentation and systematic quality work in early childhood: comparing practices in Western Australia and Sweden. Contemporary Issues in Early Childhood. https://doi.org/10.1177/1463949120 928431

Lenz Taguchi, H. (2013). Varför pedagogisk dokumentation? Verktyg för lärande och förändring i förskolan och skolan. Gleerups.

Lenz Taguchi, H. (2000). Emancipation och motstånd: Dokumentation och kooperativa processer. Stockholms Universitet.

Lenz Taguchi, H. (2010). Going beyond the Theory/Practice Divide in Early Childhood Education. Routledge.

Mansikka, J.-E. (2019). Pedagoginen Dokumentointi Reggio Emilian Ja Jälkistrukturalismin Viitekehyksessä. Journal of Early Childhood Education Research, 8(1), 100-120.

Mansikka, J.-E., \& Lundqvist, M. (2019). Barns perspektiv och delaktighet som ideologisk orientering för småbarspedagogiken $\mathrm{i}$ Finland. Nordisk tidskrift for pedagogikk og kritikk, 5, 111-129. https://doi.org/10.23865/ntpk.v5.1367

Mayring, P. (2000). Qualitative content analysis [28 paragraphs]. Forum Qualitative Sozialforschung/forum: Qualitative Social Research. https://doi.org/10.17169/fqs-1.2.1089

Paananen, M., \& Lipponen, L. (2018). Pedagogical documentation as a lens for examining equality in early childhood education. Early Child Development and Care, 188(2), 77-87. https://doi.org/10. 1080/03004430.2016.1241777

Pichio, M., Di Giandomenico, I., \& Musatti, T. (2014). The use of documentation in a participatory system of evaluation. Early Years, 34(2), 133-145. https://doi.org/10.1080/09575146.2014.897308
Repo, L., Paananen, M., Eskelinen, M., Mattila, V., Lerkkanen, M.-K., Gammelgård, L., Ulvinen, J., Marjanen, J., Kivistö, A., \& Hjelt, H. (2019) Varhaiskasvatuksen laatu arjessa-varhaiskasvatussunnitelmien toteutuminen päiväkodeissa ja perhepäivähoidossa. Kansallinen arviointikeskus. Julkaisut 15:2019.

Rintakorpi, K. (2016). Documenting with early childhood education teachers: Pedagogical documentation as a tool for developing early childhood practices. Early Years, 36(4), 399-412. https:// doi.org/10.1080/09575146.2016.1145628

Rintakorpi, K. (2018). Varhaiskasvatuksen tallentamisesta kohti pedagogista dokumentointia. Diss. Kasvatustieteellisiä tutkimuksia. Helsingin yliopisto, kasvatustieteellinen tiedekunta.

Sharmahd, N., \& Peeters, J. (2019). Critical reflection, identity, interaction. Italian and Belgian experiences in building democracy through pedagogical documentation. In J. Formosinho \& J. Peeters (Eds.), Understanding pedagogical documentation in early childhood education, revealing and reflecting on high quality learning and teaching (pp. 52-66). Routledge.

TENK. (2019). The Finnish national board on research integrity. Retrieved March 16, 2021, from https://www.tenk.fi/en

United Nations. (1989). United Nations Convention on the Rights of the Child. United Nations.

Vlasov, J., Salminen, J., Repo, L., Karila, K., Kinnunen, S., Mattila, V., Nukarinen, T., Parrila, S., \& Sulonen, H. (2019). Guidelines and recommendations for evaluating the quality of early childhood education and care. Finnish Education Evaluation Centre Publications.

Weckström, E., Lastikka, A.-L., Karlsson, L., \& Pöllänen, S. (2021). Enhancing a culture of participation in early childhood education and care through narrative activities and project-based practices. Journal of Early Childhood Education Research, 10(1), 6-32.

Publisher's Note Springer Nature remains neutral with regard to jurisdictional claims in published maps and institutional affiliations. 